\title{
Decompensated chagasic heart failure versus non-chagasic heart failure at a tertiary care hospital: Clinical characteristics and outcomes
}

\author{
Luiza Nauane Borges Azevedo dos Santos ${ }^{1}$, Mário de Seixas Rocha ${ }^{2}$, Eloina Nunes de Oliveira ${ }^{3}$, \\ Carlos Antônio Gusmão de Moura ${ }^{4}$, Ayslan Jorge Santos de Araujo ${ }^{5}$, Ítalo Magalhães Gusmão ${ }^{6}$, \\ Gilson Soares Feitosa-Filho ${ }^{7}$, Constança Margarida Sampaio Cruz ${ }^{8 *}$

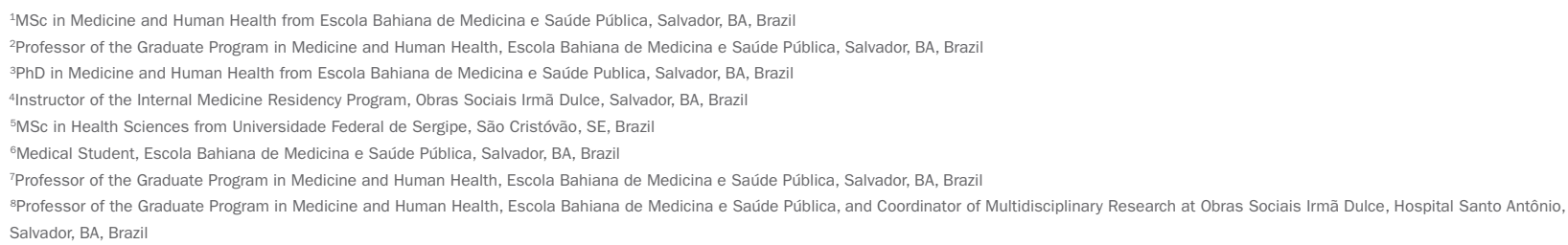

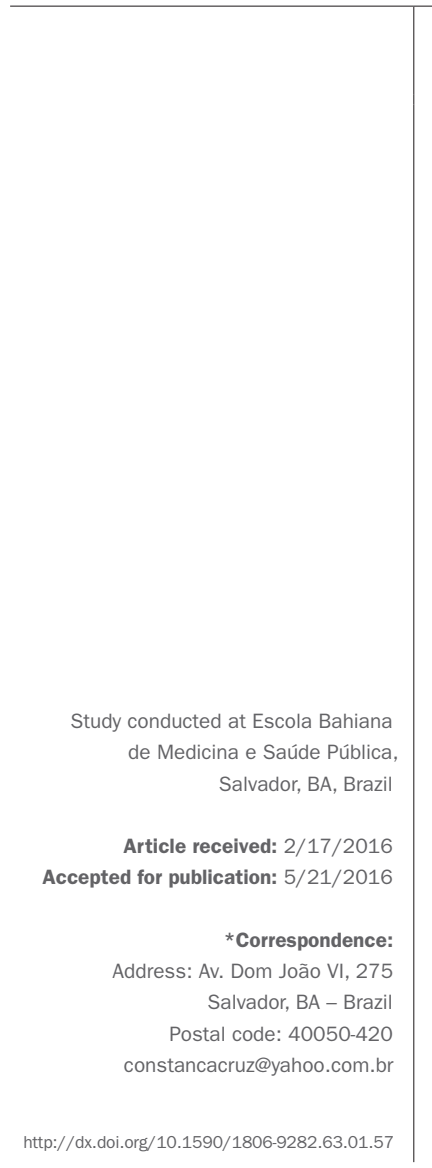

\section{SUMmarY}

Objective: To evaluate clinical and epidemiological characteristics and clinical outcomes in patients hospitalized with decompensated heart failure (DHF), with a comparison between Chagas and non-Chagas disease.

Method: This is a retrospective cohort study involving 136 patients consecutively admitted with DHF between January 1 and December 31, 2011, with the following outcomes: acute renal failure, cardiogenic shock, rehospitalization, and hospital death. Individuals aged $\geq 18$ years with DHF were included while those with more than $10 \%$ of missing data regarding outcomes were excluded. Statistical analysis was performed using SPSS version 17.0. Chi-squared test was used to compare proportions. Student's T test was used to compare means. Kaplan-Meier and log-rank tests were used to compare rehospitalization rates between the two groups over time.

Results: Chagasic and non-chagasic patients were compared. The first had lower mean systolic blood pressure $(111.8 \pm 18.4$ versus $128.8 \pm 24.4$, $\mathrm{p}<0.01)$, lower mean diastolic blood pressure $(74.5 \pm 13.6$ versus $82.0 \pm 15.2$, $\mathrm{p}<0.01)$ and lower left ventricular ejection fraction $(26.5 \pm 6.2$ versus $41.5 \pm 18.9, \mathrm{p}<0.01)$. In all, 20 patients with Chagas $(50.1 \%)$ were rehospitalized, compared to 35 patients in the non-Chagas group (35.4\%, $\mathrm{p}=0.04)$. Log rank test $=4.5(\mathrm{p}<0.01)$ showed that rehospitalization rates between the two groups over time (Kaplan-Meier curves) differed.

Conclusion: Chagas disease was associated with lower systolic and diastolic blood pressure and lower left ventricular ejection fraction. The rehospitalization rate was higher in Chagas disease.

Keywords: heart failure, chagas cardiomyopathy, patient readmission.

\section{INTRODUCTION}

Heart failure (HF) is an important public health problem, affecting around 23 million people worldwide. ${ }^{1}$ It is a pathological condition, with high mortality, that can exceed $50 \%$ within five years after diagnosis. ${ }^{2}$

The age group older than 60 years is the most affected by the syndrome, with more than $70 \%$ of hospital- izations occurring at this stage of life. National forecasts indicate that in 2025 Brazil will have the sixth largest elderly population, with approximately 30 million people, which should result in the multiplication of cases of $\mathrm{HF}$ and spending on the syndrome. ${ }^{3}$

The clinical presentation generally has an impact on quality of life, causing disability and dependency. In some 
cases, its etiology is difficult to establish due to the presence of multiple risk factors and irregular lifestyle habits. ${ }^{4}$

Among the possible etiologies of HF, Chagas disease (CD) has been showed in some studies as that with the worst prognosis. ${ }^{5}$ The state of Bahia still presents endemic outbreaks of CD and significant mortality related to its complications. Changes in the disease presentation patterns, the influence of treatment progression and outcomes need to be demonstrated, given that the largest registries of heart failure in the world usually do not include $C D$, which is a rare disease in most developed countries. Thus, studies are needed in populations where $\mathrm{CD}$ is endemic, such as in Bahia. The aim of this study was to assess the clinical characteristics and intrahospital outcomes, seeking to compare such aspects in chagasic versus non-chagasic patients.

\section{Method}

\section{Study design}

This is a retrospective cohort study with data collected from the time of hospitalization up to the patient's discharge from hospital or death.

\section{Population}

The reference population for the study corresponded to adult individuals who were admitted with ICD I500 in the period from January 1 to December 31, 2011. The patients originated from clinical wards, intensive care units, the emergency room or those transferred from other units within the hospital.

The hospital where the data was collected (Hospital Santo Antônio) is located in the city of Salvador, BA, Brazil. This is a tertiary care hospital with 1,090 beds, and only serves patients via the public health system.

\section{Sampling}

The list of patients hospitalized for decompensated heart failure (DHF) in the period from January 1, 2011 to December 31,2011 was obtained through a report provided by the archive service at the hospital where the study was conducted.

Constitution of the sample initially occurred upon request of the medical records from the service, with a total of 265 hospitalizations. The medical records of the first 136 hospitalizations were eligible. We excluded 129 hospitalizations whose data was scarce or those that related to subsequent hospitalizations in the period studied.

\section{Inclusion criteria}

Patients hospitalized due to DHF (ICD I500) aged 18 years or older. In the case of hospital readmission, only the first hospitalization within the period was considered.

\section{Exclusion criteria}

Insufficient medical record data with more than $10 \%$ of data missing in relation to the outcomes of the study.

\section{Operationalization of data collection}

Forty-one variables were collected using a standardized instrument for each patient included in the study. The data was obtained from hard copy medical records and computerized records of laboratory tests.

Independent variables: age, sex, ethnicity, marital status, occupation, cost of hospitalization, family history of heart disease, blood pressure, heart rate, respiratory rate, comorbidities such as: hypertension, diabetes, dyslipidemia, obesity, alcoholism, history of stroke, use of a pacemaker, anemia upon admission, chronic renal failure, edema, dyspnea, precordialgia, jugular stasis, hepatomegaly, and etiology of the HF.

Dependent variables: percentage of rehospitalizations, acute kidney damage defined as increased serum creatinine levels greater than $50 \%$ compared to the baseline creatinine, cardiogenic shock as mentioned in the medical records, and in-hospital death.

Data on rehospitalizations were initially collected using internal hospital records and later confirmed via telephone contact with the patient or family, considering all the rehospitalizations of the patients in the hospital during the period studied.

\section{Statistical analysis}

We used Statistical Package for Social Sciences (SPSS) version 17.0 for the statistical analysis.

The qualitative variables were expressed as absolute values and valid percentages. The quantitative variables were expressed as means \pm standard deviation in the case of a Gaussian distribution.

Descriptive statistics was used for determination of the frequencies, measures of central tendency and dispersion of the variables of interest. We used a Chi-squared test for comparison between proportions. Student's T-test was used to compare averages in the case of Gaussian distribution of the variable.

We used Kaplan-Meier curves for comparison of the rehospitalization rates in the Chagas disease group versus the non-Chagas group over time. Log-rank test $=4.5(\mathrm{p}<0.01)$.

Alpha-error of 0.05 was adopted for all of the statistical analyses.

\section{Results}

Between January 1 and December 31, 2011, there were 265 hospitalizations due to HF at Hospital Santo Antônio. A 
total of 129 patients were excluded, leaving 136 patients for analysis. The most frequently described etiology was hypertensive cardiomyopathy, affecting $42 \%$ of cases, followed by $26 \%$ Chagas cardiomyopathy, ischemic heart disease (18\%), valvular heart disease (3\%), and unknown causes (11\%).

The average age was $59 \pm 13$ years, ranging from 23 to 89 years, and $71.3 \%$ were male. In relation to ethnicity, there was a predominance of those of African descent, with a frequency of $83.8 \%$. The sociodemographic characteristics are shown in the Table 1.

TABLE 1 Sociodemographic characteristics of patients admitted to hospital with decompensated heart failure. Salvador, 2011 ( $\mathrm{N}=136)$.

\begin{tabular}{|c|c|c|}
\hline Variable & Frequency & \\
\hline \multirow[t]{2}{*}{ Gender } & Male & $71.32 \%(97)$ \\
\hline & Female & $28.67 \%(39)$ \\
\hline Age & $59.71 \pm 13.86$ & \\
\hline \multirow[t]{2}{*}{ Ethnicity } & African-descended & $83.82 \%(114)$ \\
\hline & Non-african-descended & $8.08 \%(11)$ \\
\hline \multirow[t]{4}{*}{ Occupation } & Actively working & $34.55 \%(47)$ \\
\hline & Retired & $50(49.50 \%)$ \\
\hline & Homemaker & $16(15.84 \%)$ \\
\hline & Unemployed & $27(26.74 \%)$ \\
\hline \multirow[t]{4}{*}{ Marital status } & Common-law partner & $31.61 \%(43)$ \\
\hline & Widow(er) & $14.70 \%(20)$ \\
\hline & Single & $35.29 \%(48)$ \\
\hline & Divorced & $7.35 \%(10)$ \\
\hline Drinking habit & $46(33.82 \%)$ & \\
\hline Smoking habit & $31(22.79 \%)$ & \\
\hline Arterial high & $88(64.70 \%)$ & \\
\hline \multicolumn{3}{|l|}{ blood pressure } \\
\hline Diabetes mellitus & \multicolumn{2}{|l|}{$32(23.52 \%)$} \\
\hline Dyslipidemia & \multicolumn{2}{|l|}{$8(5.88 \%)$} \\
\hline Obesity & \multicolumn{2}{|l|}{$9(6.61 \%)$} \\
\hline Anemia & \multicolumn{2}{|l|}{$66(48.52 \%)$} \\
\hline History of stroke & \multicolumn{2}{|l|}{$14(10.29 \%)$} \\
\hline Use of pacemaker & \multicolumn{2}{|l|}{$9(6.61 \%)$} \\
\hline SBP & \multicolumn{2}{|l|}{$124 \pm 24$} \\
\hline DBP & \multicolumn{2}{|l|}{$79 \pm 15$} \\
\hline HR & \multicolumn{2}{|l|}{$82 \pm 17$} \\
\hline RR & \multicolumn{2}{|l|}{$24 \pm 7$} \\
\hline Edema & \multicolumn{2}{|l|}{121 (88.97\%) } \\
\hline Dyspnea & \multicolumn{2}{|l|}{127 (93.38\%) } \\
\hline \multirow[t]{4}{*}{ Functional class } & \multicolumn{2}{|l|}{ I - 02 (1.47\%) } \\
\hline & \multicolumn{2}{|l|}{ II - 11 (8.08\%) } \\
\hline & \multicolumn{2}{|l|}{ III - 30(22.05\%) } \\
\hline & \multicolumn{2}{|l|}{ IV - 86(63.23\%) } \\
\hline
\end{tabular}

Quantitative variables are expressed as mean \pm standard deviation. Qualitative variables are expressed as a valid percentage (absolute N). SBP: systolic blood pressure; DBP: diastolic blood pressure; HR: heart rate; RR: respiratory rate.
In relation to the clinical characteristics upon admission, there was a predominance of patients with functional class IV (86 patients, 63.2\%), demonstrating impairment in the completion of daily activities, with nocturnal paroxysmal dyspnea and dyspnea on minimal exertion. The most common comorbidities were hypertension, anemia, diabetes, dyslipidemia, and obesity.

The clinical characteristics upon admission, comparing patients with Chagasic etiology with those of other etiologies, are shown in Table 2.

Among the possible outcomes considered, there were 22 deaths and 55 rehospitalizations. Acute renal damage affected 88 patients. The evaluation of the outcomes shows that chagasic patients were rehospitalized more than non-chagasic patients; $\mathrm{p}=0.04$ (Table 3). The comparison of the Kaplan-Meier curves between the two groups over time showed that: all rehospitalizations of Chagasic heart disease patients occurred in 100 to 200 days, while rehospitalization among the non-chagasic patients occurred in 300 to 365 days with a log rank test $=4.5 ; \mathrm{p}<0.01$ (Figure 1$)$.

\section{Discussion}

Despite scientific evidence showing a reduction of its prevalence in Brazil, Chagas disease constitutes a major public health problem and an important cause of heart failure in certain regions of the country. ${ }^{6}$ In our sample, we found that among the etiologies of HF, the most frequent was hypertensive heart disease, followed by chagasic heart disease.

Other studies that included patients with DHF have found different etiological distributions. In a serological survey on the prevalence of human Chagas disease conducted in Brazil, the states of Minas Gerais, Rio Grande do Sul, and Bahia presented the highest prevalence. ${ }^{6,7}$

Braga et al. ${ }^{8}$ conducted a study in Salvador with patients accompanied at outpatient clinics, showing that Chagasic heart disease was the most frequent etiology, totaling $48 \%$ of cases. Although located in the same city, our sample presented a different etiological distribution, possibly due to a time difference between the surveys, given the progressive reduction in the prevalence of Chagas disease. Freitas et al. monitored outpatients and found that chagasic patients showed a relative risk 2.26 to 2.97 higher in relation to mortality compared to other heart failure etiologies. ${ }^{9}$

In our study, the average age of chagasic patients was not significantly lower than that of non-chagasic patients. Some studies have shown an average age that is even lower in the chagasic group as a result of the pathogen- 
TABLE 2 Clinical and therapeutic characteristics of patients according to the main etiology of heart failure ( $\mathrm{N}=136)$.

Variables

Age

Male gender

Functional class I

Functional class II

Functional class III

Functional class IV

Systolic BP $(\mathrm{mmHg})$

Diastolic BP $(\mathrm{mmHg})$

Heart rate (bpm)

Edema

Carvedilol in $\mathrm{mg} /$ day

Captopril in mg/day

Furosemide in $\mathrm{mg} /$ day

Dobutamine $(\mu \mathrm{g} / \mathrm{min})$

Jugular engorgement

Anemia

Ejection fraction (EF)

History of stroke

Use of pacemaker

$2(5.4 \%)$

Chagas ( $n=37)$

$57.6 \pm 11.4$

$29(78.4 \%)$

$1(2.70 \%)$

$3(8.10 \%)$

8 (21.62\%)

$23(62.16 \%)$

$111.8 \pm 18.4$

$74.5 \pm 13.6$

$75.7 \pm 15.7$

$35(94.6 \%)$

$12.70 \pm 4.97$

$93.42 \pm 15.02$

$61.05 \pm 20.24$

$350 \pm 350$

$18(48.6 \%)$

$18(48.6 \%)$

$29.5 \pm 6.2$

$5(13.5 \%)$

Non-Chagas $(n=99)$

$60.5 \pm 14.7$

$68(68.7 \%)$

1 (1.01\%)

$8(8.08 \%)$

22 (22.22\%)

$63(63.63 \%)$

BP: blood pressure. $\left({ }^{*}\right)$ The quantitative variables are expressed as means \pm standard deviation, while the qualitative variables are expressed as absolute values (valid percentage)

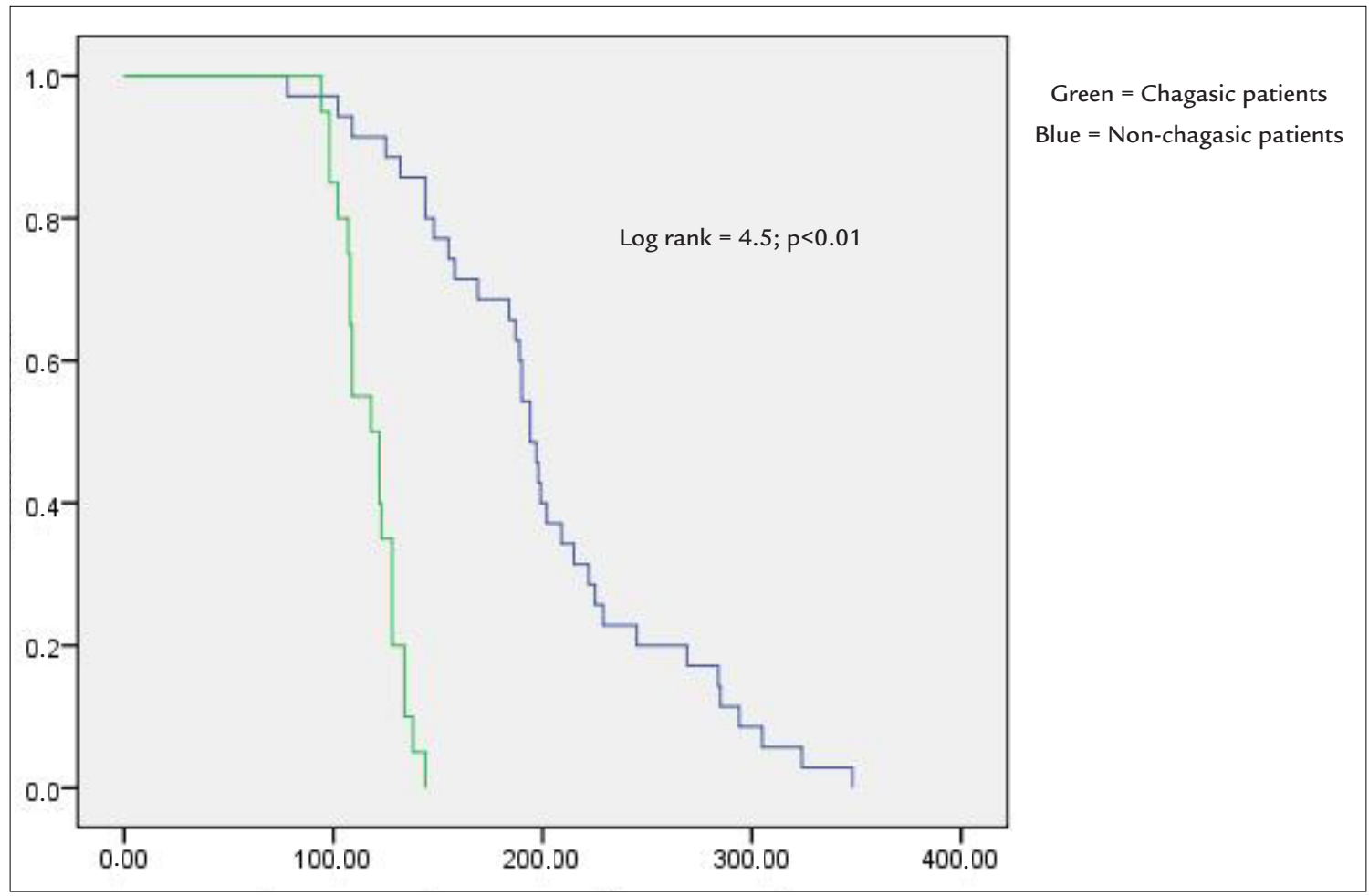

FIGURE 1 Kaplan-Meier curves showing different intervals in days for the occurrence of rehospitalization between chagasic patients and non-chagasic patients. 
TABLE 3 Type of clinical outcomes and their correlation with chagasic or non-chagasic heart failure etiology $(\mathrm{N}=136)$

\begin{tabular}{llll} 
Outcomes & Chagas (n=37) & Non-Chagas (n=99) & p-value \\
\hline Hospital death & $18.91 \%(7)$ & $15.15 \%(15)$ & 0.59 \\
\hline Rehospitalization & $54.05 \%(20)$ & $35.35 \%(35)$ & 0.04 \\
\hline Acute kidney damage & $62.16 \%(23)$ & $68.42 \%(65)$ & 0.49 \\
\hline Cardiogenic shock & $8.10 \%(3)$ & $6.31 \%(6)$ & 0.71 \\
& & & $14.73 \%(14)$ \\
\hline Arrhythmia & $24.32 \%(9)$ & & 0.19 \\
\hline
\end{tabular}

esis of the disease, such as the study by Cardoso et al., ${ }^{10}$ which found an average age of 53 years.

In relation to gender, we identified that $71 \%$ of the patients with DHF in general were male, and $78 \%$ of $\mathrm{HF}$ patients with chagasic etiology were male, as corroborated by other studies ${ }^{11-13}$ assessing elderly patients hospitalized due to the disease in our country. Braga et al., ${ }^{8}$ on the other hand, identified the male sex in $49 \%$ of the sample of chagasic patients and $55 \%$ in non-chagasic patients.

When comparing the clinical characteristics of the chagasic and non-chagasic populations there was significant difference for certain variables. Cardoso et al. ${ }^{10}$ conducted a cohort study that assessed patients with clinical hemodynamic profile $\mathrm{C}$, according to the classification given by Stevenson. Systolic blood pressure (SBP) was compared in chagasic and non-chagasic patients, resulting in $89.3 \pm 17.1 \mathrm{mmHg}$ versus $98.8 \pm 21.7 \mathrm{mmHg}$ $(p=0.03)$. In our study, we did not select patients based on their hemodynamic profile, finding an average SBP of $111.8 \pm 18.40$ in chagasic patients versus $128.8 \pm 24.40$ in non-chagasic patients $(\mathrm{p}<0.01)$. Braga et al. ${ }^{8}$ also identified lower SBP in chagasic patients, with $121 \pm 22 \mathrm{mmHg}$ compared to non-chagasic patients, with $130 \pm 26 \mathrm{mmHg}$ $(\mathrm{p}=0.001)$. Diastolic blood pressure was also significantly lower. These findings may be justified by the fact that chagasic patients exhibit more extensive myocardial destruction compared to other etiologies. ${ }^{12}$

Heart rate was found to be lower in chagasic patients, with $75.7 \pm 15.7$ versus $84.7 \pm 17.9$, with the same occurring in the study by Braga ${ }^{8}$ and Nogueira. ${ }^{7}$ Silva et al. ${ }^{12}$ relate this fact to sinus dysfunction and alteration of the autonomic nervous system, which is more common in this group.

We identified significantly lower ejection fraction in the chagasic group, which is justified by the physiopathology of CD with cardiac involvement due to extensive myocardial destruction, tissue perfusion disorders associated with dysautonomia and the presence of cardiac arrhythmias. Silva et al. also identified similar findings. ${ }^{12}$
Melo et al. studied the profile of prothrombotic and pro-inflammatory markers between chagasic and non-chagasic patients in a cross-sectional cohort study, concluding that both groups had exacerbated inflammatory activity. However, the prothrombotic status was more prominent among non-chagasic patients. ${ }^{14}$

Considering all outcomes analyzed, frequency of rehospitalizations during the period studied was the only isolated outcome presenting a significant difference while comparing chagasic and non-chagasic patients $(54.1 \%$ versus $35.4 \%$ ), respectively ( $\mathrm{p}=0.04)$. Higher frequency of rehospitalization is a marker of poor prognosis and translates into greater morbidity among chagasic patients compared to non-chagasic patients.

Recent scientific evidence has indicated a protective factor related to the use of beta blockers. Issa et al. demonstrated that the use of beta blockers has a beneficial effect on the survival of patients with heart failure caused by Chagasic diseases compared to other etiologies. ${ }^{15}$ Ayub-Ferreira et al. showed that Chagas disease was an independent predictor of death due to heart failure and all causes of death. These authors also found reduced mortality from cerebrovascular accident, other non-cardiac causes of death and longer hospital stay while comparing chagasic and non-chagasic heart diseases patients. ${ }^{16}$ In more severe cases of Chagas disease, the only treatment capable of modifying the natural history of disease is a heart transplant. Fiorelli et al. conducted a review of 107 transplant patients with a focus on disease reactivation, rejection, and mortality. The authors found the trypanosome in the myocardium of $71.8 \%$ of the transplant patients, in addition to other tissues. Hospital mortality was $17.7 \%$ due to infection, graft dysfunction, or sudden death. Late mortality was $25.2 \%$ due to rejection, infection, lymphoma, sarcoma, constrictive pericarditis, and reactivation of Chagas disease in the central nervous system. ${ }^{17}$

Clinical, socioeconomic, and organizational risk factors related to healthcare providers also have an influence. 
Monitoring should be carried out by a multidisciplinary team composed of nurses, doctors, psychologists, social workers, nutritionists, and pharmacists. A randomized study identified benefits regarding knowledge of the disease and self-care in patients exposed to an educational nursing intervention. ${ }^{18}$

\section{LIMITATIONS}

Some of the limitations of the present study are related to its clinical design. This is a retrospective study, involving observation with information retrieved from medical records gathered in several folders. The quality of the data in the medical records and the absence of systematization of the records may impair the accuracy of data collection. In addition, some patients were excluded because no serology was found to confirm or rule out the diagnosis of Chagas disease.

Another important limitation is the small sample size, which could prevent the identification of differences in low-incidence outcomes.

\section{Conclusion}

Chagas disease patients presented more severe clinical profiles than patients with other HF etiologies, with lower left ventricle ejection fraction, lower systolic blood pressure, lower diastolic blood pressure, and reduced heart rate, as well as a higher percentage of rehospitalizations.

More effective public health actions to prevent and control vector-borne transmission and transfusion transmission are necessary in our country, which still has a significant prevalence of Chagas disease.

\section{Resumo}

Insuficiência cardíaca descompensada chagásica versus não chagásica em um hospital de atenção terciária: características e desfechos clínicos

Objetivo: Avaliar características clínico-epidemiológicas e desfechos clínicos em pacientes internados por insuficiência cardíaca descompensada (ICD), estabelecendo uma comparação entre pacientes chagásicos e não chagásicos.

Método: Trata-se de um estudo de coorte retrospectivo abrangendo 136 pacientes internados consecutivamente com ICD entre 1 de janeiro e 31 de dezembro de 2011, tendo como desfechos: lesão renal aguda, choque cardiogênico, reinternamento e óbito hospitalar. Foram incluídos indivíduos com idade $\geq 18$ anos com ICD e excluídos aqueles com mais de $10 \%$ de dados faltantes em relação aos desfechos. Para a análise estatística, foi utilizado o SPSS ${ }^{\circledR}$ versão 17.0. Para a comparação entre proporções, foi utilizado o teste Qui-quadrado. O teste T de Student foi utilizado para comparar médias. Utilizamos as curvas de Kaplan- Meier e o teste do log rank para comparar as taxas de reinternações entre os dois grupos ao longo do tempo.

Resultados: Na comparação entre chagásicos e não chagásicos, os primeiros apresentaram menor média de pressão arterial sistêmica $(111,8 \pm 18,4$ versus $128,8 \pm 24,4$; $\mathrm{p}<0,01)$, menor média de pressão arterial diastólica $(74,5 \pm 13,6$ versus $82,0 \pm 15,2 ; \mathrm{p}<0,01)$ e menor fração de ejeção do ventrículo esquerdo $(26,5 \pm 6,2$ versus $41,5 \pm 18,9$; $\mathrm{p}<0,01)$. Um total de 20 chagásicos $(50,1 \%)$ reinternaram contra 35 não chagásicos $(35,4 \% ; \mathrm{p}=0,04)$. O teste do $\log$ rank $=4,5(\mathrm{p}<0,01)$ mostrou que as taxas de reinternações entre os dois grupos ao longo do tempo (curvas de Kaplan-Meier) diferiram.

Conclusão: A doença de Chagas associou-se a menores valores de pressão arterial sistólica e diastólica, além de menor fração de ejeção do ventrículo esquerdo. A taxa de reinternamento foi maior em chagásicos.

Palavras-chave: insuficiência cardíaca, miocardiopatia chagásica, readmissão do paciente.

\section{References}

1. Rossi Neto JM. A dimensão do problema da insuficiência cardíaca do Brasil e do mundo / The dimension ofthe problem of heart failure in Brazil and in the world. Rev Soc Cardiol. 2004; 14(1):1-10.

2. Tavares LR, Victer H, Linhares JM, Barros CM, Oliveira MV, Pacheco LC, et al. Epidemiologia da insuficiência cardíaca descompensada em Niterói Projeto EPICA - Niterói. Arq Bras Cardiol. 2004; 82(2):121-4.

3. Secretaria de Saúde do Estado da Bahia. Boletim Epidemiológico de Chagas, 2012

4. Nogueira PR, Rassi S, Corrêa KS. Perfil epidemiológico, clínico e terapêutico da insuficiência cardíaca em hospital terciário. Arq Bras Cardiol. 2010; 95(3):392-8.

5. Andersson B, Waagstein F. Spectrum and outcome of congestive heart failure in a hospitalized population. Am Heart J. 1993; 126(3 Pt 1):632-40.

6. Vinhaes MC, Dias JCP. Doença de Chagas no Brasil. Cad Saúde Pública. $2000 ; 16(1): 7-12$.

7. Nogueira PR, Rassi S, Corrêa KS. Perfil epidemiológico, clínico e terapêutico da insuficiência cardíaca em hospital terciário. Arq Bras Cardiol. 2010; 95(3):392-8.

8. Braga JCV, Reis F, Aras R, Costa ND, Bastos C, Silva R, et al. Aspectos clínicos e terapêuticos da insuficiência cardíaca por doença de Chagas. Arq Bras Cardiol. 2006; 86(4):297-302.

9. Freitas HF, Chizzola PR, Paes AT, Lima AC, Mansur AJ. Risk stratification in a Brazilian hospital-based cohort of 1220 outpatients with heart failure: role of Chagas' heart disease. Int J Cardiol. 2005; 102(2):239-47.

10. Cardoso J, Novaes M, Ochiai M, Regina K, Morgado P, Munhoz R, et al . Cardiomiopatia chagásica: prognóstico no perfil clínico-hemodinâmico C Arq Bras Cardiol. 2010; 95(4):518-23.

11. Barretto A, Drumond Neto C, Mady C, Albuquerque DCD, Brindeiro Filho DF, Braile DM, Bocchi EA, et al. Revisão das II Diretrizes da Sociedade Brasileira de Cardiologia para o diagnóstico e tratamento da insuficiência cardíaca. Arq Bras Cardiol. 2002; 79(1):1-30.

12. Silva CP, Del Carlo CH, Oliveira Junior MT, Scipioni A, Strunz-Cassaro C, Ramirez JAF, et al. Por que os portadores de cardiomiopatia chagásica têm pior evolução que os não-chagásicos? Arq Bras Cardiol. 2008; 91(6):389-94. 
13. Villacorta H, Rocha N, Cardoso R, Gaspar S, Maia ER, Bonates T, et al Evolução intra-hospitalar e seguimento pós-alta de pacientes idosos atendidos com insuficiência cardíaca congestiva na Unidade de Emergência. Arq Bras Cardiol. 1998; 70(3):167-71.

14. Melo LMMP, Souza GEC, Valim LR, Moreira LFP, Damico EA, Rocha TRF, et al. Study of pro-thrombotic and pro-inflammatory factors in Chagas cardiomyopathy. Arq Bras Cardiol. 2010; 95(5):655-62.

15. Issa VS, Amaral AF, Cruz FD, Ferreira SM, Guimarães GV, Chizzola PR, et al. Beta-blocker therapy and mortality of patients with Chagas cardiomyopathy: a subanalysis of the REMADHE prospective trial. Circ Heart Fail. 2010; 3(1):82-8.
16. Ayub-Ferreira SM, Mangini S, Issa VS, Cruz FD, Cruz FD, Bacal F, Guimarães GV, et al. Mode of death on Chagas heart disease: comparison with other etiologies. a subanalysis of the REMADHE prospective trial. PLoS Negl Trop Dis. 2013; 7(4):e2176.

17. Fiorelli AI, Santos RH, Oliveira JL Jr, Lourenço-Filho DD, Dias RR, Oliveira AS, et al. Heart transplantation in 107 cases of Chagas' disease. Transplant Proc. 2011; 43(1):220-4.

18. Bocchi EA, Cruz F, Guimarães G, Moreira LFP, Issa VS, Ayub Ferreira SM, et al. Long-term prospective, randomized, controlled study using repetitive education at six-month intervals and monitoring for adherence in heart failure outpatients: the REMADHE trial. Circ Heart Fail. 2008; 1(2):115-24. 